\title{
Europos respiratologų draugijos sunkios astmos SHARP projektas Europoje ir Lietuvoje
}

\author{
KRISTINA BIEKŠIENE் \\ LSMU MA Pulmonologijos klinika
}

Europos respiratologų draugijos (ERS) CRCs (angl. Clinical Research Collaborations) programa teikia paramą ịvairioms kvèpavimo medicinos sritims, kad būtų sukurti ir veiktų Europos daugiacentriai tyrèjų tinklai. Sunkios astmos ERS CRC vadinamas SHARP CRC (angl. Severe Heterogeneous Asthma Research collaboration, Patient-centred Clinical Research Collaboration).

$2019 \mathrm{~m}$. vasario $22 \mathrm{~d}$. Lietuvos pulmonologų ir alergologų draugija (LPAD) surengè jau antrą tradicija tampančia Sunkios astmos konferenciją. Džiaugiamès, kad joje dalyvavo ERS SHARP projekto vadovas profesorius R. Djukanovic iš Sautamptono universiteto (Jungtinè Karalystè).

Šio projekto pagrindiniai tikslai: keisti sunkia astma sergančiu pacientų gyvenimą, glaudžiai bendradarbiaujant pacientams, klinicistams, mokslininkams, farmacijos industrijai, palaipsniui ịsitraukiant ir politikams; harmonizuoti astma sergančių pacientų priežiūrą Europoje, paraleliai siekiant mokslo ir klinikinès praktikos sąveikos, greitinant mokslo pasiekimų diegimą $\mathfrak{i}$ klinikinę praktiką. Pagal ERS SHARP viziją, dirbant kaip vieningai komandai, siekiama šiu tikslų: 1) astmos kontrolei pasiekti nebebūtų naudojami geriamieji gliukokortikoidai; 2) visi sunkia astma sergantys pacientai patektu pas sunkios astmos specialistus; 3) gilinti žinias apie sunkios astmos mechanizmų heterogeniškumą; 4) siekti užkirsti kelią vystytis sunkiai astmai.

ERS CRC SHARP veiklos nukreiptos $\mathfrak{i}$ pacientus, kurie yra lygiaverčiai projekto partneriai. Tai yra pirmas ERS CRC, kuriame tarp pirmininkaujančiu yra pacientai, kurie dalyvauja ir bendradarbiauja visose ERS SHARP veiklose. Pacientai taip pat teikia pasiūlymus moksliniams tyrimams jiems rūpimais klausimais.
Vienas svarbiausių ERS SHARP projekto tikslu - pereiti nuo atskirų, skirtingų prie vieningo Europos sunkios astmos registro bei naujų registrų sukūrimo šalyse, kuriose jų dar nèra. Sunkios astmos registras sudarytų sąlygas turèti realios klinikinès praktikos, ilgalaikès stebėsenos, gydant biologine terapija, geros kokybès duomenis. ERS SHARP registro tikslai: 1) išsiaiškinti paūmèjimų mechanizmus pacientams, kuriems biologinè terapija neveiksminga; 2) numatyti, kuriems pacientams bus stebimas geras gydymo biologine terapija atsakas; 3) ịvertinti turimus biožymenis (eozinofilų kiekis, azoto monoksido frakcija iškvepiamame ore, FeNO) bei vystyti ir validuoti naujus; 4) sveikatos ekonomikos, susijusios su sunkia astma, gilesnès žinios leistų tinkamai planuoti lëšų paskirstymą. ERS SHARP mokslinių tyrimų pagrindinès temos turètų atsakyti $\mathfrak{i}$ šiuos klausimus: 1. Kaip Europoje skiriasi sunkia astma sergančių pacientų charakteristikos ir gydymas? 2. Kokie yra sunkios astmos paūmèjimų mechanizmai, įskaitant jų priežastis ir pasekmes bei gydymą? 3. Koks geriausias būdas tirti pacientų, sergančiu sunkia astma, rezultatus?

ERS SHARP projekto pagrindinè misija - tinkamas vaistas tinkamam pacientui tinkamu laiku.

Lietuva $2018 \mathrm{~m}$. vasarị tapo šio projekto nare. ERS SHARP atstové Lietuvai - Kauno kliniku Pulmonologijos klinikos doc. $\mathrm{K}$. Biekšienè. Igyvendinant SHARP projektą Lietuvoje, įkurtas Kauno klinikų Sunkios astmos centras, parengtos Sunkios astmos diagnostikos ir gydymo rekomendacijos, i̇vyko jau dvi sunkios astmos kasmetinès konferencijos. Sudarytas ir igyvendintas planas „žaliasis koridorius“, skirtas sunkia astma sergantiems pacientams greičiau patekti pas III lygio pulmonologus, dir- 


\section{Aktualijos}

bančius sunkios astmos centre, sukurta Sunkia astma sergančių pacientų, gydomų biologine terapija, priežiūros sistema. Taip pat vykdoma įvairi edukacinè, švietejjiška veikla, gerinant žinomumą, gilinant žinias apie sunkią astmą, Sunkios astmos centrą bei SHARP projektą. Tai pat vykdoma mokslinè veikla sunkios astmos srityje.

ERS SHARP projekto vadovas prof. R. Djukanovic apsilankè Kauno klinikų Pulmonologijos klinikoje, kur susitiko su klinikos vadovu prof. S. Miliausku, Kauno klinikų generaliniu direktoriumi prof. R. Jurkevičiumi. Taip pat dalyvavo moksliniame seminare, kurio metu buvo supažindintas su Sunkios astmos centro veikla. Pulmonologijos klinikos doktorantai, vadovaujami prof. K. Malakausko (V. Kalinauskaitė-Žukauskè, I. Janulaitytė bei A. Januškevičius), supa- žindino profesorių su klinikoje vykdomais moksliniais tyrimais sunkios astmos srityje. Profesorius pateike puikių patarimų jauniesiems mokslininkams, skatindamas juos toliau tobulèti ir tęsti savo mokslinę veiklą. Konferencijos metu susirinkę dalyviai išklausė prof. R. Djukanovic pranešimą apie sunkios astmos diagnostikos bei gydymo strategiją Europoje.

ERS SHARP projekto Lietuvoje perspektyvos yra sunkios astmos registro sukūrimas, remiantis vieninga SHARP platforma, pacientų ittraukimas ị veiklą, susijusią su sunkia astma. Sieksime glaudesnio bendradarbiavimo su šeimos gydytojais, II lygio pulmonologais, atrenkant ir siunčiant sunkia astma sergančius pacientus ị Sunkios astmos centrą, taip pat plètojant mokslinę veiklą. 